\title{
Challenges in Islamic Visual Art
}

\author{
Wan Samiati Andriana W Mohamad Daud ${ }^{1}$, Dzul Haimi Md Zain ${ }^{2}$ \\ ${ }^{1}$ Faculty of Art and Design, Universiti Teknologi MARA, Sarawak \\ ${ }^{2}$ Faculty of Art and Design, Universiti Teknologi MARA, Shah Alam
}

\begin{abstract}
This paper aims to discuss the development and challenges of Islamic Visual Arts in Malaysia. Art was often considered as mere entertainment, focusing more on temporal and fun aspects. However, art in the perspective of Islam is considered as part of the human nature and needs. The Islamic concept of art leads people to witness the Oneness of Allah (Tawheed) which eventually brings them to the submission of Allah SWT. Islam encompasses all aspects of human life in which a person as an individual was not complete without the religious consciousness. Malaysia gained the independence in 1957, however, the acceptance of Islamic people towards Western secularism or liberalism has placed Islam as part of other religions and this dualism has affected the general pattern of thought and life of the community.
\end{abstract}

Keywords: Challenges, Visual Art, Islam.

\section{INTRODUCTION}

Aminah Syed Muhammed (1983) states that before the coming of Islam to Malaysia, animism, Hinduism and Buddhism were the main religions that made up the local culture and in fact, the evidence of their influence still remains until today.

However, the explosive development of information technology, especially in the era of globalization has brought a huge challenge to moral and cultural integrity of the country. Internet, for example, allows users to get all kinds of knowledge and information with ease, but at the same time it contains a lot of information that are destructive, immoral and contrary to the values as well as ethics of religion and culture of a society.

Islam is a religion revealed by Allah SWT to the entire universe. Therefore, Islam is a religion that is always relevant, appropriate and compatible with human nature in which it meets and fulfills all human needs, characteristics, desires, feelings, soul and mind. Allah SWT creates man, which by nature comes with soul, emotion, conscientiousness and compassion towards beautiful things. Hence, in this context, art is an entity that has beauty and subjective in nature. It can be seen, heard and touched by one's soul even though it sometimes could not be expressed through words and language. In other words, it is difficult to define art precisely and it is even more difficult to explain the concept of beauty and elegance in art.

\section{RESEARCH STUDY}

Tolstoy (1896) mentioned art as a means of communication in which it transfers the emotional sense of an artist. While Read (1959) defines art as an attempt to create shapes and forms which brings pleasure. Pleasure shapes and forms must be construed as shapes and forms that captures and places the beauty.

Ismail R. al-Faruqi dan Lois Lamya 'al-Faruqi (1992) defined Islamic art as a manifestation of suitable aesthetic values because it is bound to the real or actual knowledge which discloses Islam based on the Quran. In other words, any message contains in Islamic artworks should be based and in line with the real or actual knowledge and message contained in the Quran.

Robert Irwin (1982) states that Islamic art is also referred as an Islamic culture and is not only as an art related to Islam. Furthermore, Islamic art is not art of a particular era or for a particular place or for specific people and does not restrict to certain movement. 
According to Aminah Syed Muhammad (1995), almost any work of art reflects Islam except those done in a wrong way, and the roots of contemporary Islamic art which firmly developed in the West and non-Muslims in traditional art. Those values are promoted by the West and therefore are often contradicted with Islam.

Faith has become the key factor for the construction of Islam. Islam began when the Muslim artist proclaim his testament with La ilahailla Allah (There is no god but Allah) and accept the notion of Tawhid (Oneness) that Allah is One . Tawhid is a solid concept that does not only describe the Muslim worldview of God, but also their worldview of the world as well as their role in life as an individual and a member of the society.

Azhar (2012) stated that Aqidah (Belief) in terms of linguistic means faith or strong belief. While Aqidah in terminology means a definite belief and a fixed decision which is not mixed with any suspicion or doubt, regardless whether it is true or not based on the two types of proof, dalil naqli and aqli. A dalil naqli is derived from a textual source, taught and transmitted to the one making the argument, while dalil aqli is derived from formal or informal logic, inductive reasoning, deductive reasoning, or other modes of intellection. The knowledge of Aqidah is the science of faith discussing matters related to belief and confidence towards Allah SWT.

\section{Discussion}

The West still think that art as something that is related to the moral and idealistic in which art has two different approaches, first, art for the sake of art and second, art for the community. Art for art is to make or create any artistic creation to deliver messages, whether good or bad. On the other hand, art for the community is for the purposes of social, political and moral.

Dzul Haimi (2001) written that Islamic art historiography went through a vacant state of substance and its continuity has been fulfilled with the knowledge of Western art. Sometimes we are in the discipline of art history very anxious to talk about a particular art as a piece of Islamic art. Our assessment was overshadowed by Western thought that were not Islamic even a real Islamic artwork is not considered as Islamic art. This situation was very disappointing.

Dzul Haimi (2001) further added that the discipline of art history has been dominated by the West. Western formulas have been used in studying the history of Islamic art and the Western world view can not be contained in their teodologi. Consequently, this has caused some problems in the writings of the history of Islamic art. Instead, the methodology used in the Islamic research should be based on the Quran.

Islam generally defines art as a value involving both aesthetic and ethical, between beauty and good. If Islam specifically is to give a focus on the concept of beauty, it would be similar to the "art for art" philosophy, which ignores the aspects of good and bad, this will create an excessive attitude in art where it is totally against the teachings of Islam. Allah SWT says:

O children of Adam, take your adornment at every masjid, and eat and drink, but be not excessive. Indeed, He likes not those who commit excess. (Al-A'raff: verse 31)

According to Muliyadi Mahamood (1992), there are two important factors that initiate Islamic Art in Malaysia. First is the National Cultural Congress that sets the Cultural Policy (National Cultural Policy) in 1971 and the second factor is due to the global revival of Islam. Mohamad Ali Abdul Rahman (2000) noted that the National Cultural Congress held on 16th to 20th August 1971 was considered to play important role in starting a new phase in Malaysian society. Three key principles outlined by the congress are:

- Islam as a basis in the development of national culture.

- Malaysian culture must be based on the culture of the indigenous people in this region.

- Elements from other cultures that are reasonable and in line with the above can be accepted as an aspect of the culture of the country

Ahmadrashidi Hassan (2012) explained that the number of writing and publishing on the development of Islamic art in Malaysia has declined greatly, yet still there are some research, writing and publication of Islamic art in Malaysia that could be considered important and obvious. The lack of such texts in terms of quantity and quality are caused by the feeling of dissatisfaction among those involved in the art industry in Malaysia (Sarena, 2010). 
In addition, Ahmadrashidi Hassan (2012) claimed that most of the exhibitions which uphold Islamic Art as the theme started from years of 80s and 90s. University of Malaya was the pioneer in Islamic Art exhibition in 1975 with an exhibition entitled 'Pameran Seni Khat' (Exhibition of Calligraphy). The exhibition was organized by the Cultural Center of the University. Besides, there were other several exhibitions held inclusive of 'Rupa dan Jiwa' (1979), 'Ke Arah Tauhid' (1980), 'Seni Rupa Islam Malaysia (1991),' Identiti Islam Kami Profesional Dalam Seni Rupa Malaysia, Pencapaian dan Cabaran '(1992), 'Manifestasi Jiwa Islam' (1993), 'Kesenian Islam, Suatu Perspektif Malaysia' (1995) Seni dan Kerohanian '(1995),' Gema Infinity '(1996),' Pameran Alam Melayu '(1999), 'Insyirah' (2001), 'Yang Maha Esa: Kepada Mu Kekasih' (2010) and 'Taman Naluri' (2013).

In addition, there are also some groups and solo exhibitions of Islamic art have been held in this country. All these activities clearly show the existence of a large amount of works done to support the development of Islamic Art in Malaysia.

Nevertheless, Zakarian Ali (2013) mentioned that there are some artists in Islamic Art who have been well known for so long. Zakarian Ali has translated many artists' artworks, whether verbally or in writings. According to him, the Malays themselves have been influenced by western culture which has been introduced through technology and education. Living in the modern world with many restraints including time, finance and space have led the Muslims slowly forgetting the Malay Art and culture of Islam as well as the Islamic Arts.

\section{Conclusion}

Art is a discipline that combines many other aspects including philosophy, aesthetics, cultural science, psychology, anthropology, history and comparative studies. In terms of accent art, art origin, art development, art innovation, art appreciation, art propaganda, it generates rules, future trends, changes and development of human art.

Aqidah (belief) becomes a fundamental part in the development of Islam. Islam began with the artist, declare their witnesses (the testimony), La ilahailla Allah (There is no god but Allah), muhammadarasullullah, (and Muhammad is the Messenger of Allah) and accept the concept of the Oneness of God means that Allah is One.

Art is used as a tool to spread the religion and strengthen charity and kindness among the community (Ummah). Through artistic talent, Muslim artists can use a variety of techniques and art as extensive power to remember and praise the greatness of Allah SWT. Therefore it becomes a responsibility of the artist to translate the idea of Islam into the language of art. According to the Islamic perspective, artistic creativity is the desire or power given by Allah SWT, which gives priority to Allah SWT In addition, art also enhances unity or cohesion. Islamic art is not about the individual human being, but it has social orientation, based on the needs amongst the human beings themselves.

\section{APpreciation}

Praise is to Allah SWT, with His countless blessing, eventually this paperwork managed to be presented successfully, Alhamdulillah. Peace and Blessings be upon our beloved Prophet SAW. This opportunity, I would proudly convey my deepest appreciation to all parties involved, either directly or indirectly throughout the process of completing this paperwork. All the cooperation that has been obtained from all parties involved will always be remembered. Last but not least, I do hope that we will together continue to get the blessing from the Almighty, continue to gain happiness in this world and the hereafter, InsyaAllah.

\section{REFERENCES}

[1] Abdul Ghani Samsudin. 2001.Seni Dalam Islam.Cetakan kedua. Petaling Jaya: Intel Media. pg 3.

[2] Ahmadrashidi Hassan. 2012. Contemporary Islamic Painting in Malaysia 1980 to 2000. UiTM: UiTM Press. pg 3-8.

[3] Aminah Sayyid Muhammed. (2ed) 1995. Islamization of the Visual Arts. Toward Islamization of Disciplines.pg 483-493.

[4] Aminah Sayyid Muhammed. 1984. Pameran Seni Lukis \& Seni Khat, Pameran Tamadun Islam (katalog Pameran). Balai seni Lukis Negara.

[5] Australian High Commission. 1980. Ke Arah Tauhid, Kuala Lumpur: Australian High Commission. 
[6] Azhar Abdul Rahman. 2012. Memahami Kerangkaan Islam. UiTM, Penerbitan Press.

[7] Dzul Haimi bin Md Zain. 2013. Ta'biran dan Penghayatan Seni Islam, dalam Katalog Pameran Taman Nurani, Islamic Impressions in Malaysia Contemporaray Art. K.L, Galeri Petronas.

[8] Dzul Haimi Md. Zain. 2001. Ilham 2001 (Katalog Pameran). UiTM Shah Alam.

[9] Faculty of Art and Design. 1997. Echoes of Infinity, Shah Alam: Institut Teknologi MARA.

[10] Herbert R. 1959. The Meaning of Art, New York: Pinguin Book.pg. 1.

[11] Islam dan Kebudayaan Melayu. Kuala Lumpur: Kementerian Kebudayaan, Belia dan Sukan. pg. 77.

[12] Ismail R. Faruqi. 1980. Islam and Culture.Kuala Lumpur: Angkatan Belia Islam Malaysia. pg 38.

[13] Mohamad Ali Abdul Rahman. 2000. Modern Malaysia Art: Manifestation of Malay Form and Content. Biroteks UiTM: Shah Alam. pg 63

[14] Muliyadi Mahamood. 1992. Tiga Generasi Pelukis Kajian Seni Lukis dan Seni Reka. Fantasi, Julai . Kuala Lumpur: Creative Enterprise. pg.82

[15] National Art Gallery. 1991. Seni Rupa Islam Malaysia, Kuala Lumpur: National Art Gallery.

[16] National Art Gallery. 1992. Identiti Islam Dalam Seni Rupa Malaysia, Pencapaian dan Cabaran, Kuala Lumpur: National Art Gallery.

[17] National Art Gallery. 1993. Menifestasi [sic] Jiwa Islam, Kuala Lumpur, National Art Gallery.

[18] National Art Gallery. 1995. Kesenian Islam, Suatu Perspektif Malaysia, Kuala Lumpur: National Art Gallery.

[19] National Art Gallery. 1995. Art and Spirituality, Kuala Lumpur: National Art Gallery.

[20] Zakaria Ali. (2013). Masa hadapan Seni Islam, from Catalog ofPameran Taman Nurani, Islamic Impressions in Malaysia Contemporaray Art. K.L, Galeri Petronas.

Citation: Wan Samiati Andriana W, Mohamad Daud, and Md Zain Dzul Haimi. "Challenges in Islamic Visual Art." International Journal of Humanities Social Sciences and Education (IJHSSE), vol 4, no. 8, 2017, pp. 15-18. doi:http://dx.doi.org/10.20431/2349-0381.0407006.

Copyright: (C) 2017 Authors. This is an open-access article distributed under the terms of the Creative Commons Attribution License, which permits unrestricted use, distribution, and reproduction in any medium, provided the original author and source are credited. 